\title{
PROPOSED MODEL FOR THE USE OF CLEAN DEVELOPMENT MECHANISM TO ATTRACT FOREIGN DIRECT INVESTMENT TO EGYPT
}

\author{
Ezzat, F. A. ${ }^{(1)}$; Omran, M. M. ${ }^{(2)}$; Saleh, A. M. ${ }^{(3)}$ \\ and Allam, M. A. E. A. ${ }^{(4)}$
}

1) Faculty of Commerce, Ain Shams University 2) Arab Academy for Science, Technology \& Maritime Transport 3) Institute of Environmental Studies and Research, Ain Shams University 4) Commercial Counselor, Egyptian Commercial Service

\begin{abstract}
The Clean Development Mechanism (CDM) is the Kyoto Protocol mechanism. The Mechanism has two main objectives; to assist Annex I Parties to cost-effectively fulfil part of their emission reduction targets under the Kyoto Protocol, and to help non-Annex I Parties in achieving sustainable development. When the CDM entered into force on 16 February 2005, its implemented projects, in non-Annex 1 developing countries, created certified emission reductions (CERs). So the project participants can sell to Annex I Parties to help them meet their Kyoto Protocol targets, they can also provide complementary benefits to non-Annex I Parties such as new investment, climate friendly technology transfer and know-how, skills development, employment..etc

Based on the literature review, none of the studies assessed the clean development mechanism from the point of comparative benchmarking anaylsis between several countries. Most of the studies focused solely on the carbon climate and its economics away from the overall country business climate, competition and investment policies. Attrating foreign direct investments, even for environmental purposes, is an economic activity and there is a need to assess and test how to integrate the promotional activities for environmental projects into the country investment promotion strategy.
\end{abstract}


This study was conducted in order to propose a model and action plan to benefit from the clean development mechanism in order to attract foreign direct investment to Egypt. To be able to gather the necessary data, the researcher utilized descriptive method using both qualitative and quantitative approaches. Herein the chosen responded governmental officials were selected from the assigned Egyptian ministries responsible for investment and environmental affairs. Structured interviews was the research method used for data gathering to evaluate the challenges that facing the inclusion of clean development mechanism within Egypt's investment opportunities, and to reach out the potential sector and targeted foreign countries to invest in Egypt's CDM projects. The compiled values and statistical analysis utilized the official data released from the UNFCCC secretariat along with the official investment data of Egyptian General Authority for Investments and Free Zones and the official reports of related global indicators.

The results of the study may help the decesion maker to integrate more the environmental projects into the investment policies. Despite the uncertainity that might shape the future of $\mathrm{CDM}$, the researcher would like to stress on the need to capitalize on CDM benfits and to learn from the other peer developing countries experience. The proposed model may be used as a catalyst towards more integration of the CDM framework into the country investment climate and doing business activities.

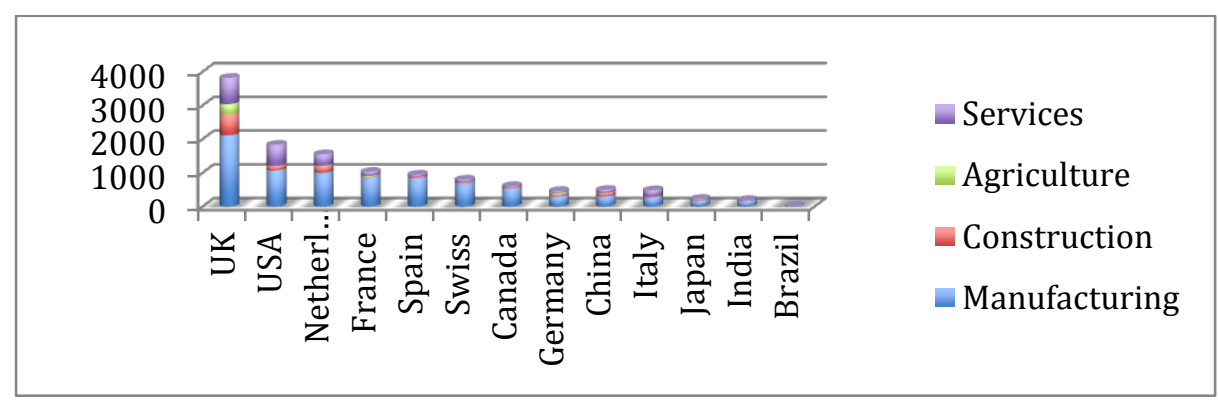

Figure (1): List of Suggested Sectors \& Countries to Target in CDM 


\section{INTRODUCTION}

The Kyoto Protocol of The United Nations Framework Convention on Climate Change (UNFCCC) entered into force on 16 February 2005. The Protocol contains legally binding emissions targets for industrialized countries listed in Annex I of the agreement; these so-called "Annex I countries" are to reduce their collective emissions of six key greenhouse gases by at least $5 \%$ on average over the period 2008 - 2012, compared with 1990 levels. in December 2012, Parties to the Kyoto Protocol agreed on a second commitment period started from January 2013 till 2020. A total of 144 instruments of acceptance are required for the entry into force of the amendment. As of November 2015, only 51 parties have ratified the amendment.At the time when this research started by 2009 there were evolving evidence about the benefits of CDM, and its effectiveness towards combating climate change. The end of the first commitment period of the Kyoto Protocol (2008-2012) marked a turning point in the history of the clean development mechanism (CDM), as the CDM now suffers from a huge lack of demand, which reflected the supply and demand misbalance. On the other hand, The post-Kyoto architecture for 2012-2020 foresees substantial financial transfers from developed countries to the developing world. Financial transfers are to reach US $\$ 100$ bn by 2020, much of which will come directly from government budgets. Development finance means that governments, not the market decide where best to allocate capital. This may increase equity of climate finance flows, but not efficiency. This trade-off can be better managed if markets provide the right signals for capital allocation(Martin S. \& Tanya W. 2014 ). 


\section{RESEARCH PROBLEM}

As the Clean Development Mechanism (CDM) has evolved, it has become clear that it provides developed and developing countries with opportunities. The former can hope for a cheap way to meet their obligations under the Kyoto Protocol, whilst the latter see the CDM as a tool for promoting sustainable development and technology transfers. Despite these high hopes, there are doubts surrounding the CDM. So is the main problem of this study on the attempt to figure out how to use clean development mechanism to attract foreign direct Investments. As there is no linear relationship between the clean development mechanism and the investment consolidation activities. The research aimed to assess the relation between the Clean Development Mechanism and Foreign Direct Investments and to reach a proposed model for Egypt to use CDM to attract FDI.

\section{HYPOTHESIS}

1. If the country has better economic and environmental performance, then it will attract more Clean Development Mechanism projects.

2. If the country lacks incentives and investment guarantees, then it will not host Clean Development Mechanism projects.

3. If the country suffers from the absence of sources of funding and the high risks of investors' confidence, then it will host limited number of Clean Development Mechanism projects. 
4. If the country ability to establish advanced technology and innovation hubs for industrial purposes is limited, then it will be unqualified to establish environmentally friendly industry.

\section{RESEARCH OBJECTIVES}

a- To benchmark Egypt's position and ranking on economic and environmental indexes with China, India, Brazil, and South Africa ones. In this research I assessed the main categories and subcategories of the 6 major global indexes for the period of 10 years from 2006 till 2015, to develop proposed statistical model.

b- To examine the level of coordination in the area of using CDM to attract FDI and to develop recommendations to enhance opportunities to benefit from the CDM. The researcher had interviews with governmental officials responsible for investment promotion in general and cleans development mechanism.

c- To identify short list of suggested potential foreign countries to target to invest in Egypt and the sectors related to the CDM based on the analysis of the foreign direct investment inflows to Egypt for the period of 25 years from 1985 till 2015.

\section{METHODOLOGY}

This study was conducted in order to propose a model and action plan to benefit from the clean development mechanism in order to attract foreign direct investment to Egypt.To be able to gather the necessary data, the researcher utilized descriptive method using both qualitative and quantitative approaches.Herein the chosen responded governmental officials were selected 
from the assigned Egyptian ministries responsible for investment and environmental affairs. Structured interviews was the research method used for data gathering to evaluate the challenges that facing the inclusion of clean development mechanism within Egypt's investment opportunities, and to reach out the potential sector and targeted foreign countries to invest in Egypt's CDM projects. The compiled values and statistical analysis utilized the official data released from the UNFCCC secretariat along with the official investment data of Egyptian General Authority for Investments and Free Zones and the official reports of the below mentioned global indicators;

- The Environmental Performance Index;

- Energy Sustainability Index;

- Foreign Direct Investment Confidence Index;

- The Global Opportunity Index;

- The Doing Business report;

- The Global Competitiveness report.

The credibility of the findings, proposed statistical model, suggested action plan, and conclusions extensively depend on the quality of research design, data collection, data management, and data analysis.

\section{Unit of Analysis:}

Egypt, China, India, Brazil, and South Africa are the units of analysis of the research. China, India, Brazil, and South Africa are the Key non-annex 1 developing countries of Kyoto Protocol, which forms more than $80 \%$ of the CDM market (CDM fact sheet, UNFCCC), and prominent emerging economies. 


\section{Data Analysis:}

The researcher analyzed global investment indicators in the clean development mechanism projects in order to identify the key countries investing in the global CDM projects.

Based on the foreign direct investment inflows to Egypt for the last 25 years from 1985 till 2015, the researcher analysed on yearly basis 191 foreign country investment inflows to Egypt on sectorial distribution as follows; Industrial, Construction, Services, Agriculture, and Financial Services.

The researcher compared the list of Top countries investing globally in CDM projects with the List of Egypt Top Foreign Investors according to their exact annual capital inflows per sector.

The researcher surveyed the related governmental entities responsible for investment promotion, industrial modernaization, and the clean development mechanism (by interviewing their representative(s) in order to assess the CDM market in Egypt and to examine the level of coordination in the area of using CDM to attract FDI and to develop recommendations to enhance opportunities to benefit from the CDM. The researcher developed guideline questionnaire to follow it through out the interviews. The researcher had meetings and interviews, and communications with officials and representatives from the governmental entities responsible for Investment and Environment during the period from 2009 till 2015.

The research-benchmarked Egypt's position and ranking on economic and environmental indexes with China, India, Brazil, and South Africa ones. The research assessed the main categories and subcategories of the following 6 major indexes for the period of 10 years from 2006 till 2015 taking into 
consideration the starting period of the implementation of the Clean Development Mechanism. The indexes are as follows:

- The Environmental Performance Index;

- Energy Sustainability Index;

- Foreign Direct Investment Confidence Index;

- The Global Opportunity Index;

- The Doing Business report;

- The Global Competitiveness report.

\section{Description of the variables:}

The statistical analysis contains 4 main sections one for each hypothesis. Inside each section, the researcher described and made the following; The suggested variables to test this hypothesis, Descriptive statistics for these variables in each country, Bivariate relations between the variables, and Proposal of the suggested statistical model.

\section{Variables of each Hypothesis:}

1. H1: If the country has better economic and environmental performance, then it will attract more Clean Development Mechanism projects.

1.1 Description of the variables: To test the above hypothesis the researcher suggested the following variable, which can describe each of development scale, and projects under clean development mechanism as follow:

A- Development scale (economic and environmental performance independent variables): the following variables are the variables that the researcher see can measure the development scale: 
- GDP

- Net FDI

- Portfolio equity

- Economic indicator (this indicator is calculated as weighted average from sub-indicators "doing business, FDI confidence, and global opportunity index"

- Percentage of volume of emissions (demand) / sum all gases emissions (supply).

- Environmental index (this indicator is calculated as weighted average from sub-indicators "environmental performance index, and energy sustainability index" respectively.

- GCI rank

B- Projects under clean development mechanism (dependent variables): the following variables are the measurable ones (for the sake of the research subject) related to economics of clean development mechanism.

- Number of hosted CDM projects

- Number of issued units of CER's

- Estimated capital investment of CDM projects.

2. H2: If the country lacks incentives and investment guarantees, then it will not host Clean Development Mechanism projects.

2.1 Description of the variables: To test the above hypothesis the researcher suggested the following variable, which can describe each of development scale, and projects under clean development mechanism as follow: 
1- Benefits and investment guarantees for projects (independent variables): the following variables are the variables that the researcher sees that it could measure the development scale:

a- Protecting investor rank (sub index extracted from Doing Business Report)

b- Enforcing contracts (sub index extracted from Global Competitiveness Report).

c- FDI confidence

d- Business impact of rules on FDI (sub index extracted from Global Competitiveness Report):

2- Projects under clean development mechanism (dependent variables):

- Number of hosted CDM projects

- Number of issued units of CER's

- Estimated capital investment of CDM projects.

3. H3: If the country suffers from the absence of sources of funding and the high risks of investors' confidence, then it will host limited number of Clean Development Mechanism projects.

3.1 Description of the variables: To test the above hypothesis the researcher suggested the following variables, which can describe the absence of funding and high risks in this area as follow:

a- Absence of funding (independent variables): the following variables are the variables that the researcher sees that it could measure the absence of funding: (All are sub indexes extracted from Global Competitiveness Report): 
I. Availability of financial services

II. Financing through local equity market

III. Ease of access to loans

IV. Venture capital availability

V. Financial market development

b- High risks (independent variables): Trustworthiness and confidence.

c- Dependent variable: Number of hosted CDM projects.

4. H4: If the country ability to establish advanced technology and innovation hubs for industrial purposes is limited, then it will be unqualified to establish environmentally friendly industry.

4.1 Description of the variables: To test the above hypothesis the researcher suggested the following variable, which can describe the lack of advanced technology, funding and financial capacity and environmentally friendly industry as follows:

a- Lack of advanced technology (independent variables): the following variables are the variables that the researcher see can measure the lack of advanced technology (All are sub indexes extracted from Global Competitiveness Report):

1- Availability of latest technology

2- Firm-level technology absorption

3- FDI and technology transfer

4- Innovation

5- Innovation and sophistication factors. 
b- Funding and financial capacity (independent variables): the following variables are the variables that the researcher see can measure the Funding and financial capacity (All are sub indexes extracted from Global Competitiveness Report):

1- Availability of financial services

2- Financing through local equity market

3- Ease of access to loans

4- Venture capital availability

5- Financial market development

c- Environmentally friendly industry (dependent variables): the following variables are the variables that the researcher see can measure the Environmentally friendly industry:

1- Environmental Performance index

2- Energy Sustainability index

3- Capacity for innovation (sub index extracted from Global Competitiveness Report)

4- Business sophistication (sub index extracted from Global Competitiveness Report)

(All indicators are ranking of countries which 1 means best country) 


\section{DISCUSSIONS, RESULTS' OF STATISTICAL ANALYSIS \& FINDINGS}

\section{Section 1:}

The research surveyed both governmental sectors responsible for investment promotion in general and clean development mechanism in order to assess the CDM market in Egypt and to examine the level of coordination in the area of using CDM to attract FDI and to develop recommendations to enhance opportunities to benefit from the CDM. The researcher developed guideline questionnaire to follow it through out the interviews. The researcher had meetings and interviews, and communications with officials and representatives from the following governmental entities during the period from 2009 till 2015.Based on the interviews and collected data from the governmental entities, the study reached the following results:

1. To use CDM to attract FDI, the Clean Development Mechanism stakeholders in Egypt should be ; GAFI, IMC, the Egyptian DNA, CDM investors, existing and potential CDM companies.

2. The five most important industries your agency specifically targets with respect to low-carbon foreign investments and the importance of technology transfer for these industries:

\begin{tabular}{|rl|l|}
\hline \multicolumn{2}{|c|}{ Target Industries } & Level of Importance \\
\hline \hline 1. & Cement Industries & Extremely Important \\
\hline 2. & Fertilizers Industries $-\mathrm{f}$ & Extremely Important \\
\hline 3. & Steel Industries & Extremely Important \\
\hline 4. & petroleum refinery & Very Important \\
\hline 5. & Textile Industries & Somewhat Important \\
\hline
\end{tabular}

3. There is policy limitation for GAFI to promote for new investment projects related to high energy consuming industries and contribute 
heavily to environmental pollution. This concern needs to be addressed to transfer it to Environmental opportunity to tackle environmentally friend projects in the following industries fertilizers, cement, and steel.

4. There is a crucial need for Egypt to secure sustainable financial sources to finance CDM projects and environmental protection projects in general. Till July 2011, There were 25 projects seeking finance in Waste, Industry, Fuel Switching, Energy Efficiency sectors.

5. In year 2006, GAFI has approved the establishment of the first CDM Company (Austrian company) in Egypt under the investment incentives \& guarantee law.

- The Austrian company implements the biggest CDM project (N2O abatement) in the world, Abu Kir Fertilizers, which has a total annual emissions reduction of 1.8 million tons $\mathrm{Co} 2$ equivalent.

- The CDM project is fully financed by the Austrian company.

- Revenues generated from the sale of the generated CERs are being mutually shared by the Egyptian fertilizers company and the Austrian investor.

6. The Environment to Investment dialouge and collaborations with regard to the CDM concentrated mainly during the period from 2008 till 2010 and had its pay offs, several market problems have been diagnosed and investment barriers have been clearly set out.

7. The following bareriers are the main challenges facing the CDM market:

- Definition of market size: there is no clear cut information on the CDM market size in Egypt, the number and size of the projects eligible for CDM 
implementation is vague.

- Low awareness of the CDM and the importance of implementation: despite the several awareness campaigns (more than 25 awareness workshops) conducted by the Egyptian DNA, still many Egyptian factories and projects candidates ignore the concept of CDM, and even those who are aware of the concept they underestimate the importance of application.

- Lack of the qualified Egyptian expertise in the field of CDM consultancy: as there are no Egyptian companies operating in the field of CDM consultancy, in order to sincerely adopt the implementation of Egyptian CDM projects (few examples of Arabian CDM consultancy companies exist in the global market).

- Small and medium scale projects have a greater market share: as this size of projects exists heavily in the Egyptian industry and foreign investors always seek the large scale projects at the lowest risk and investment costs.

- Bundling is the unutilized tool in the market: despite the large percentage of small \& medium size projects in the market.

\section{Section 2:}

The research benchmarked Egypt's position and ranking on economic and environmental indexes with China, India, Brazil, and South Africa ones. The research assesed the main categories and subcategories of the following 6 major indexes for the period of 10 years from 2006 till 2015 taking into consideration the starting period of the implementation of the clean development mechanism. Committed to the regulation of the publishing, in this part, the researcher will focus on the First Hypothesis "The more the 
country advanced on development scale the more projects under the clean development mechanism attracted"

In this hypothesis the researcher fits three factors of dependent variable on the pervious discussed independent variables.

\section{It was proven with the proposed Statistical Model:}

No of hosted CDM projects

$$
\begin{aligned}
& =0.061 * G D P+1.951 * F D I+6.430 * \text { portfolio equity } \\
& +1.386 * \text { percentage of } \frac{\text { demand }}{\text { supply }}-4.235 * G C I
\end{aligned}
$$

NO. of issued units of CER's

$$
\begin{aligned}
& =14643 * G D P+498516 * F D I+1099986 \\
& * \text { portfolio equity }-970770 * \text { GCI }
\end{aligned}
$$

Estimated capital investment of CDM projects

$$
\begin{aligned}
& =0.001 * G D P+0.038 * F D I-0.084 \\
& * \text { environmental indicator }-0.250 * G C I
\end{aligned}
$$

- Increasing GDP by one unit will increase No. of hosted CDM projects by 0.061 unit on average fixing other factors and this with confident $95 \%$.

- Increasing FDI by one unit will increase No. of hosted CDM projects by around two units on average fixing other factors and this with confident $95 \%$.

- Increasing portfolio equity by one unit will increase No. of hosted CDM projects by 6.4 unit on average fixing other factors and this with confident $95 \%$. 
- Increasing percentage of demand/supply by $1 \%$ will increase No. of hosted CDM projects by 1.4 unit on average fixing other factors and this with confident $95 \%$.

- Improving of the country competitiveness ranking on GCI by one will increase No. of hosted CDM projects by 4.2 unit on average fixing other factors and this with confident $95 \%$.

- Increasing GDP by one unit will increase number of issued units of CER's by 14643 units on average fixing other factors and this with confident $95 \%$.

- Increasing FDI by one unit will increase number of issued units of CER's by 498516 units on average fixing other factors and this with confident $95 \%$.

- Increasing portfolio equity by one unit will increase number of issued units of CER's by 1099986 units on average fixing other factors and this with confident 95\%.

- Improving of the country competitiveness ranking on GCI by one level will increase number of issued units of CER's by 970770 units on average fixing other factors and this with confident $95 \%$.

- Increasing GDP by one unit will increase estimated capital investment of CDM projects by 0.001 units on average fixing other factors and this with confident $95 \%$.

- Increasing FDI by one unit will increase estimated capital investment of CDM projects by 0.038 units on average fixing other factors and this with confident $95 \%$. 
- Improving the country ranking of environmental indicator by one will increase estimated capital investment of CDM projects by 0.084 unit on average fixing other factors and this with confident $95 \%$.

- Improving of the country competitiveness ranking on GCI by one will increase estimated capital investment of CDM projects by 0.250 unit on average fixing other factors and this with confident $95 \%$.

\section{Section 3:}

- The research targeted the potential investment countries and sectors related to the CDM for Egypt based on the analysis of the net foreign direct investment inflows to Egypt for the 25 years from 1985 till 2015.

- The researcher identified the key countries investing in CDM market, then compared these set of countries with the List of Egypt Top Foreign Investors according to their exact annaul capital inflows per sector. Then the researcher extracted the sector related to the CDM market. The follwing Table summarize the the Suggested List of these countries. 
Table (1): Exact Value of Country Participation in valuable Investment Sectors related to CDM (Value: million US \$)

\begin{tabular}{|c|c|c|c|c|c|c|c|}
\hline & Manufacturing & Construction & Agriculture & Services & Subtotal & Finance & Total \\
\hline \hline UK & 2106.47 & 622.36 & 304.72 & 779.15 & 3812.7 & 443.59 & 4818.94 \\
\hline USA & 1068.34 & 116.43 & 13.23 & 628.49 & 1826.49 & 904.12 & 2835.54 \\
\hline Netherlands & 996.02 & 184.89 & 19.03 & 345.6 & 1545.54 & 644.17 & 2464.29 \\
\hline France & 860.63 & 20.02 & 25.34 & 119.33 & 1025.32 & -116.81 & 908.51 \\
\hline Spain & 840.72 & 45.45 & 0 & 55.16 & 941.42 & & 941.42 \\
\hline Swiss & 673.15 & 32.94 & 6.35 & 82.13 & 794.57 & 131.44 & 926.01 \\
\hline Canada & 533.84 & 42.47 & 5.03 & 22.16 & 603.55 & 2.37 & 655.04 \\
\hline Germany & 295.68 & 51.54 & 48.83 & 60.29 & 455.58 & -1.45 & 570.66 \\
\hline China & 295.05 & 87.92 & 13.5 & 90.69 & 487.16 & 0 & 591.35 \\
\hline Italy & 264.76 & 17.86 & 3.675 & 190.74 & 477.035 & 939.64 & 1540.01 \\
\hline Japan & 157.17 & 14.25 & 10.93 & 40.46 & 222.81 & 35.32 & 258.55 \\
\hline India & 144.86 & 5.43 & 3.96 & 36.83 & 193 & 0.09 & 212.04 \\
\hline Brazil & 11.57 & 1.23 & 0 & 4.45 & 17.25 & 0 & 18.04 \\
\hline \hline
\end{tabular}

Source: Egyptian General Authority for Investment

\section{Recommendations:}

For the Egyptian CDM market to become more investor attractive, at first investment barriers related to awareness and definition of the CDM market size has to be resolved. In this regard, Both GAFI \& EEAA have to set out an implantable action plan with clear objectives of:

1. Scouting for potential CDM projects;

2. Benefiting from the transfer of technology associated with the implementation of the projects;

3. Attracting more FDI to the CDM sector, this plan to be implemented jointly with the Egyptian DNA and in collaboration with the private sector. 


\section{The action plan includes:}

\section{Step one:}

The development of a nation wide CDM Business survey in collaboration with the Egyptian Business Associations and Federation of Industries: The purpose of the survey is to use as a tool for scouting activities.

Step Two: Scouting for potential CDM projects in the market: based on the result of the previous step, Collaboration between the key stakeholders including the business entities with the purpose of scouting for CDM projects within the industry sector;

Decision has to be taken GAFI to use the results of developed survey in scouting for potential CDM projects within the Egyptian free zones and industrial zones.

Awareness of the CDM concept and importance of application will be accompanying the scouting activities undertaken during this step.

\section{Step three:}

Based on the results of the Section 3 of this part of the study, the researcher suggested list of potential targeted countries and sectors. In this step, it is recommended to target these countries for the sake of promotion of the selected eligible projects to: This step to be performed by the GAFI in collaboration with the Egyptian DNA. 


\section{CONCLUSION}

In light of our own experience in the field of CDM, the researcher can conclude that for the use of CDM to attract FDI is a cooperative model; individual or separate efforts will not lead to improvements. In this regard, it is important to build deep and comprehensive model of cooperation between investment and environment related governmental entities in Egypt to improve the economic benefits of carbon:

- Awareness and capacity building efforts to potential CDM companies on the importance of applying the CDM concept is very important.

- The national DNA should have more effective role in the scouting process of new CDM investment opportunities.

- More cooperation efforts between the Investment Promotion Entities and the national DNA must be exerted in the filed of promotion for potential CDM projects.

- National private sector investors must be involved in the investment process not only foreign investors.

On the other hand, official talks and dialogue with Egypt's top investment partners need to established and to address the following:

- Funds allocated for the mitigation of the green house gas effect should give more priority to most affected sector.

- To reap the benefits of investments available in the CDM field a less timeconsuming registration process should be taken into consideration as the current one could take 18 months.

- Allocating more funds on scientific studies assessing the negative effect of global worming on each individual developing country, in order to 
highlight future potential investment field or even potential business in danger.

\section{CHARTS \& PICTURES}

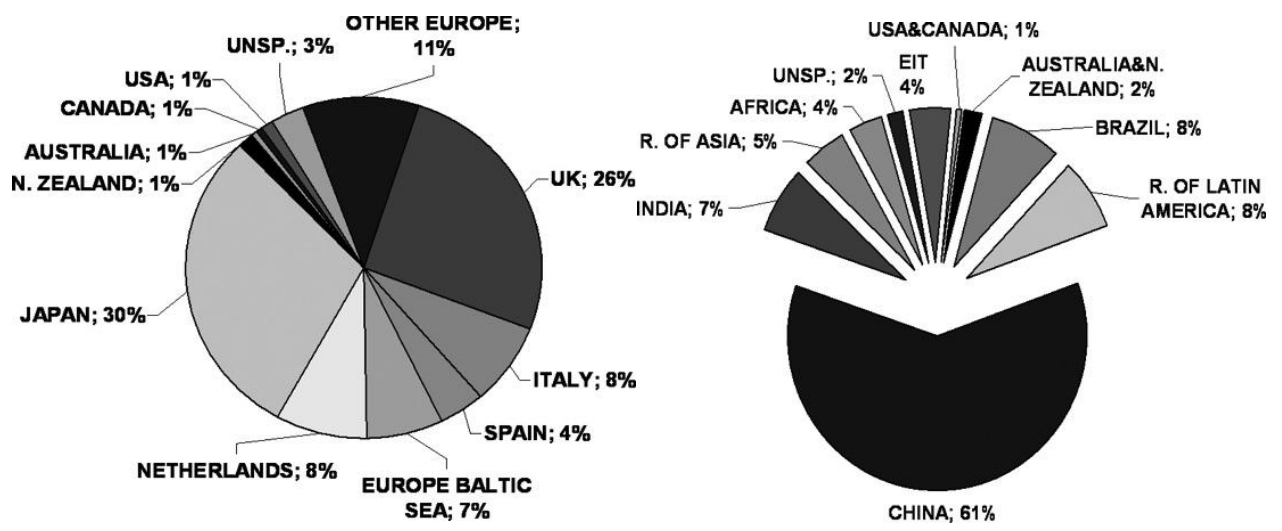

Figure1. Major buyers Vs. Major sellers in project-based transactions of CDM (Source: Capoor and Ambrosi 2006b)

\section{REFERENCES}

Aldy, J., S. Barrett, \& R. Stavins. (2003): Thirteen plus one: a comparison of alternative climate policy architectures. Climate Policy 3: 373-97.

Ariel D,Donald FL, \& Shaokh M R.(2010): The Clean development Mechanism an early History of Unanticipated Outcomes, Volume 1.World Scientific , 1(1), 2(11-13)

Barrett, S. (2003): Environment and State craft. New York: Oxford University Press.

Barretto, L., \& S. Kypreos. (2004): Emissions trading and technology deployment in an energy- system 'bottom-up' model with technological learning. European Journal of Operations Research 158: $243-61$. 
Carr, E. H. (1939): The Twenty Years' Crisis, 1919-1939, New York, NY: Harper and Row.

Claussen E. \& L. McNeilly (2000): Equity and Global Climate Change: The Complex Elements of Global Fairness, PEW Center on Global Climate Change, VA, USA.

Egyptian Intended Nationally Determined Contributions (INDCs) towards achieving the objectives of the United Nations Framework Convention on Climate Change,(November 2015)., P (5-6)

ECORYS. (2013): Exchange of Good Practice in Foreign Direct Investment Promotion. Rotterdam: ECORYS Nederland BV, $156 \mathrm{p}$.

Fenhann, J. (2006): Overview of the CDM Pipeline, version Oct. 2006.

Martin S. \& Tanya W. (6 August, 2014 ). The CDM: The power of markets should be reignited for the 2015 Paris climate agreement.

Narula, R., Dunning, J.H. (2010): Multinational enterprises, development and globalisation: Some clarifications and a research agenda. Oxford Development Studies, 38 (3), p. 263-287.

UNFCCC STUDY,(2012): Benefits of The Clean development Mechanism UNFCCC Study. UNFCCC, P(8). 


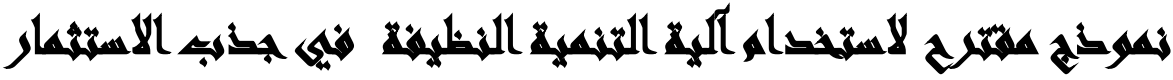 الأجنهيه المهاشر إليه همر
}

[11]

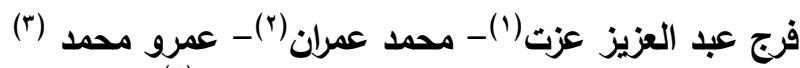

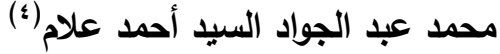

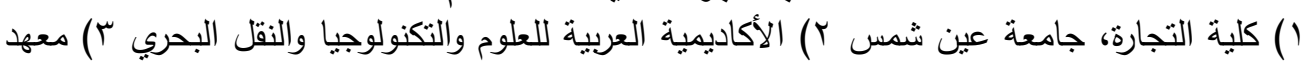

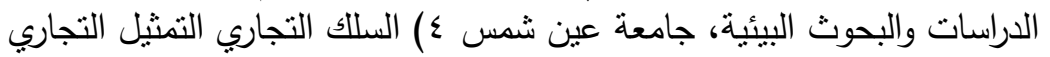

\section{المستخليف}

تهدف اتفاقية الأمم المتحدة الإطارية للتغيرات المناخية لتنبيت نركيزات غازات الاحتباس الحراري

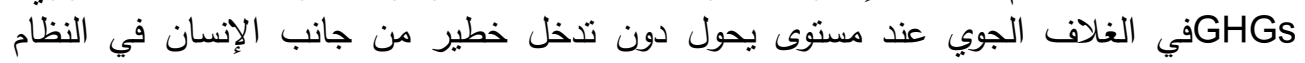
المناخي، ويتم ذلك عن طريق وضع التزامات على الدول المتقدمة (الصناعية) بتخفيض البحن التعاثاتها،

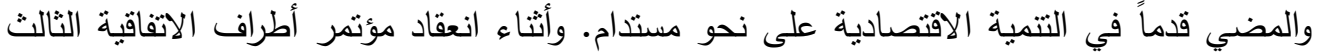

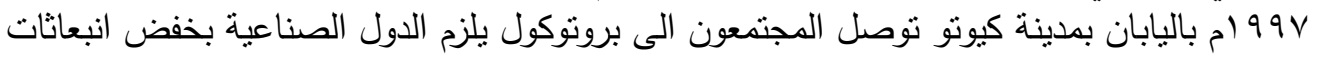

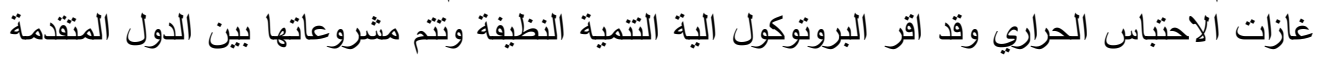

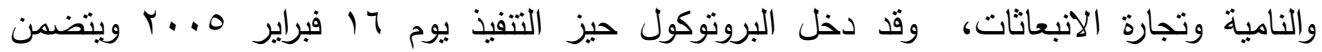

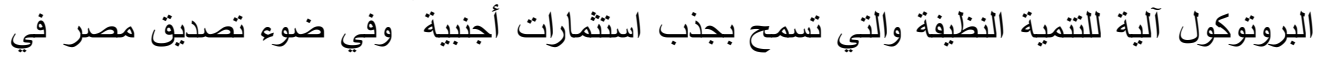

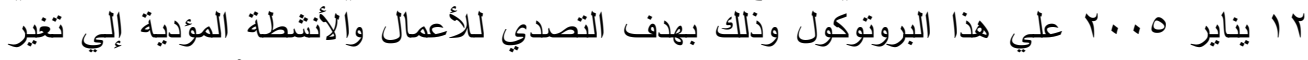

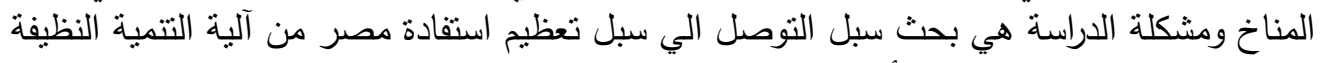

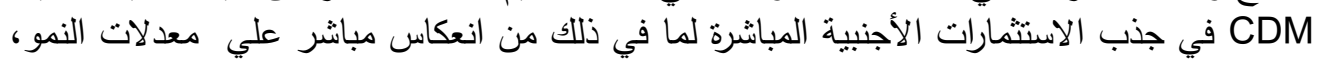

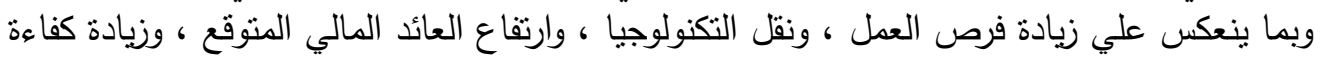

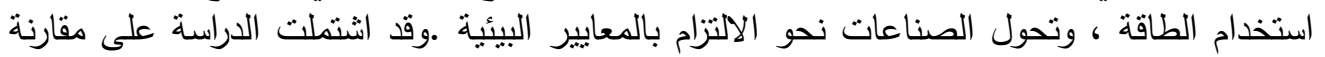

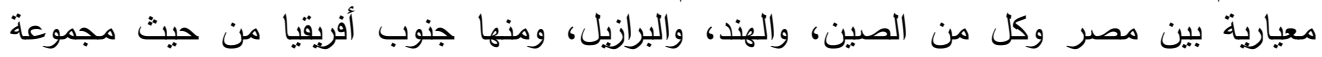

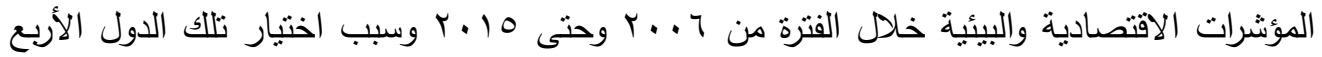

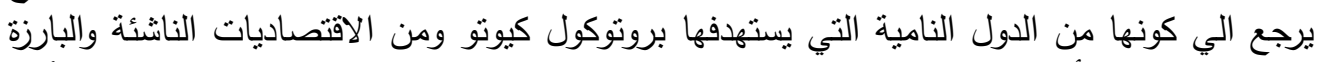

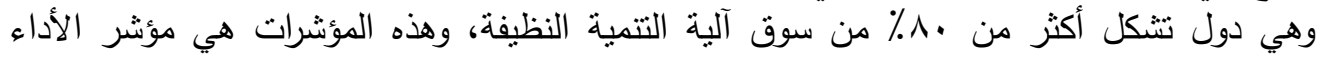

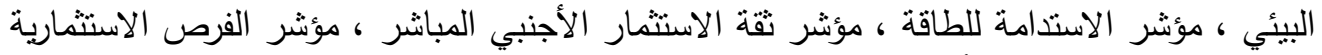

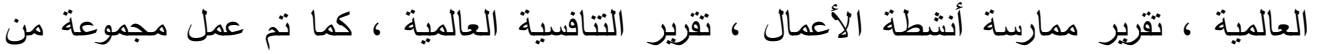

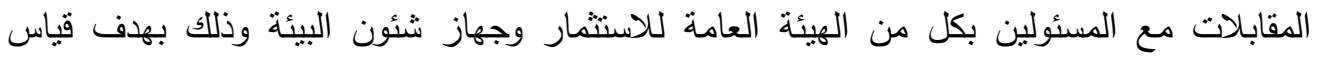

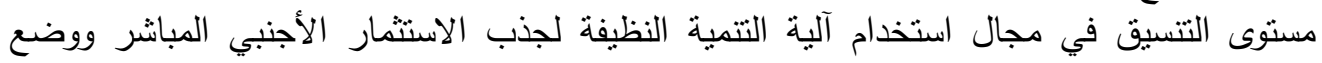


وقد نوصلت الدراسة الي معوقات استخدام آلية التتمية النظيفة في جذب الاستثمارات الأجنبية ومنها:

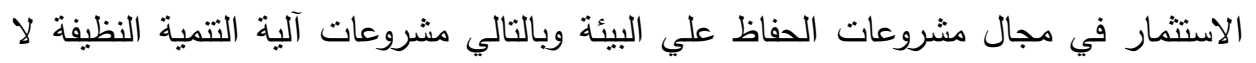

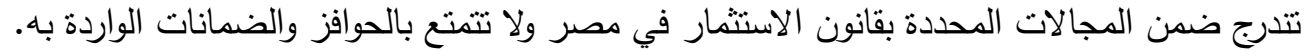

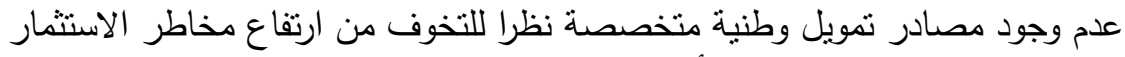

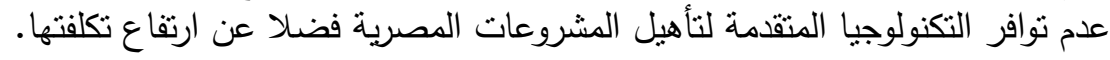

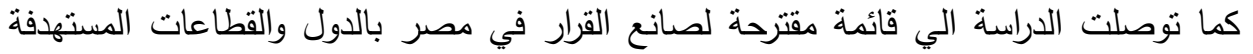
لجذب استثمارات أجنبية في مشروعات مرنبطة بالبيئة. 